\title{
PENGARUH MOTIVASI DAN KEPEMIMPINAN TERHADAP KINERJA PEGAWAI UNIVERSITAS PGRI PALEMBANG
}

\author{
Chandra Kurniawan \\ Dosen FKIP Universitas PGRI Palembang \\ e-mail: chandrakurniawan79@gmail.com
}

\begin{abstract}
The purpose of this study was to determine the effect of motivation and leadership on employee performance in Universitas PGRI Palembang. The research method used was survey with quantitative explanative approach. The population in this research were the administrative staff of Universitas PGRI Palembang which consist of 388 people. The sampling technique used was Proportionate Stratified Random Sampling where sampling method taken from the population is done proportionally by taking into account the strata in the population. The number of samples taken was $10 \%$ of the total population of 39 respondents. Statistical analysis used for hypothetical action in this research was descriptive analysis and path analysis. The results of the analysis showed that (1) the better motivation of employee performance of Universitas PGRI Palembang, then the performance of employees will also be increased; (2) The better the leadership in Universitas PGRI Palembang, then the performance of employees will also be increased; and (3) the joint better of motivation and leadership on the performance of Universitas PGRI Palembang, then the performance of Universitas PGRI Palembang staff will also be increased.
\end{abstract}

Keywords: Motivation, Leadership, Universitas PGRI Palembang

\section{PENDAHULUAN}

Perguruan tinggi merupakan salah satu lembaga pendidikan yang secara formal diserahi tugas dan tanggung jawab mempersiapkan mahasiswa sesuai dengan tujuan pendidikan nasional, yaitu mengisi kebutuhan masyarakat akan tersedianya tenaga ahli dan tenaga terampil dengan tingkat dan jenis kemampuan yang sangat beragam. Karena itu mahasiswa sebagai peserta didik dan generasi muda yang mempunyai kedudukan dan peranan penting dalam mewujudkan cita-cita pembangunan nasional, senantiasa perlu dibimbing dan dikembangkan. Menurut Peraturan Pemerintah No. 60 tahun 1999, perguruan tinggi menyelenggarakan pendidikan dalam upaya menghasilkan manusia yang terdidik sesuai dengan tujuan pendidikan tinggi, melakukan penelitian dalam upaya menghasilkan pengetahuan empirik, teori, konsep metodologi, model atau informasi baru yang memperkaya ilmu pengetahuan, teknologi dan kesenian, dan pengabdian pada masyarakat yang merupakan kegiatan yang memaanfaatkan ilmu pengetahuan dalam upaya memberikan sumbangan demi kemajuan masyarakat.

Dalam penyelenggaraan pendidikan, penelitian dan pengabdian pada masyarakat tersebut muncul berbagai tantangan seperti penempatan posisi pendidikan tinggi secara 
tepat di era globalisasi, tuntutan kualitas, relevansi pendidikan dengan kebutuhan masyarakat, peningkatan daya saing peneliti dalam menghasilkan karya yang bermutu, munculnya inovasi teknologi dan informasi yang semakin cepat dan pengkajian komprehensif terhadap proses perubahan struktur masyarakat.Untuk mengantisipasi tantangan-tantangan tersebut maka keberadaan perguruan tinggi sebagai salah satu lembaga pendidikan, pembinaan, dan pencetak kader-kader bangsa yang berkualitas dan bermoral haruslah melakukan inovasi.

Inovasi tersebut dapat berupa program layanan, metode, teknologi, proses dan kinerja. Inovasi tersebut kemungkinan hanya dalam bentuk mengadopsi, namun dalam mengimplementasikannya dilakukan secara terus-menerus dan disesuaikan dengan situasi dan kondisi perguruan tinggi yang bersangkutan. Undang-undang No. 2 tahun 1989 tentang Sistem Pendidikan Nasional menyebutkan bahwa perguruan tinggi dapat berbentuk Akademi, Politeknik, Sekolah Tinggi, Institut, atau Universitas. Pendidikan tinggi ini dapat diselenggarakan oleh Pemerintah, dalam hal ini Departemen Pendidikan dan Kebudayaan (Perguruan Tinggi Negeri-PTN), departemen atau lembaga pemerintah yang lain (Perguruan Tinggi Kedinasan-PTK), atau oleh masyarakat (Perguruan Tinggi Swasta-PTS). Penyelenggaraan tujuan pendidikan nasional yang dilakukan oleh berbagai pihak merupakan suatu usaha yang dilakukan untuk hasil yang maksimal dalam pencapaian kecerdasan masyarakat. Masalah pendidikan adalah masalah yang sangat luas dalam cakupannya, oleh karena itu masalah ini tidak dapat hanya dilakukan oleh pemerintah saja.

Menyikapi permasalahan diatas dalam ruang lingkup Administrasi Publik dikatakan bahwa, pemerintah perlu melakukan kemitraan terhadap pihak lain untuk mencapai tujuan negara dalam hal ini adalah masyarakat, seperti yang dinyatakan oleh Dwight Waldo (dalam Riant Nugroho, 2004 : 10). Kemitraan antara negara dan swasta adalah bentuk pencapaian kesejahteraan bersama antara pemerintah dan masyarakat, sehingga akan sangat sulit bagi pemerintah dalam menjalankan fungsi-fungsinya jika tidak melakukan kerjasama kepada pihakpihak swasta dalam mencapai tujuan pendidikan nasional. Didasarkan pada teori dan pendapat tersebut serta Undang - undang No. 2 Tahun 1989 tentang sistem pendidikan nasional, penyelenggaraan kegiatan kependidikan yang dikelola oleh institusi ataupun lembaga swasta merupakan bentuk kemitraan antara negara dan masyarakat. Keberadaan PTS swasta menjadi wadah yang 
baik untuk mencerdaskan masyarakat yang semakin berkembang dan luas. Dalam hal ini tidak mungkin pemerintah akan menangani sendiri kebutuhan pendidikan masyarakat yang demikian tingginya dengan keterbatasan lembaga-lembaga penyedia pendidikan. Universitas-universitas negeri yang ada merupakan lembaga utama pemerintah dalam mencapai tujuan pendidikan nasional sedangkan swasta merupakan mitra dari negara untuk lebih memaksimalkan tercapainya tujuan tersebut.

Universitas PGRI Palembang hadir sebagai salah satu lembaga pendidikan yang merupakan mitra pemerintah, selalu berupaya menyiapkan diri dengan menyandarkan pada paradigma baru dalam pengelolaan perguruan tinggi yang diwujudkan dalam bentuk peningkatan kualitas, otonomi, akuntabilitas, akreditasi dan evaluasi. Langkah baru dalam pengelolaan perguruan tinggi ini tidak lain untuk memenuhi minat dalam kebutuhan masyarakat Provinsi Sumatera Selatan akan pendidikan yang lebih tinggi. Kebutuhan masyarakat dimaksud bukan semata-mata sebagai obyek bagi Universitas PGRI untuk meningkatkan kualitasnya, namun lebih dari itu didorong oleh keinginan bahwa para pendiri dan pengelola Universitas PGRI Palembang dalam meningkatkan sumber daya manusia yang berkualitas dan bermoral.
Sampai dengan saat ini berdasarkan data dari bagian kepegawaian Universitas PGRI Palembang telah memiliki 381 orang pegawai dengan berbagai macam latar belakang pendidikan, S-1 228 orang, S-2 56 orang, S-3 6 orang, Diploma 23 orang, dan SMA 67 orang yang terbagi - bagi di setiap bagian untuk melayani mahasiswa serta melaksanakan tugas administrasi. Dari data dan jumlah pegawai yang cukup banyak sebetulnya sangat memungkinkan untuk pencapaian hasil kerja yang optimal dan cepat. Akan tetapi kondisi yang ada di Universitas PGRI Palembang menunjukkan bahwa sebagian pegawai mempunyai kinerja yang rendah, walaupun mereka telah mempunyai kemampuan yang relatif memadai.

Pencapaian kinerja yang tidak maksimal terlihat dari hasil program kerja yang dicapai oleh para pegawai pada bagian ini. Rata-rata hasil yang dicapai hanya mencapai nilai 55\% dari hasil yang diharapkan. Padahal bagian ini merupakan bagian yang cukup penting dan sangat vital karena bagian ini berhubungan dengan pengelolaan keuangan dan kepegawaian dibawah koordinasi Pembantu Rektor II. Tentu saja hal ini sangat mempengaruhi prodiktivitas kinerja yang dicapai selama ini. Berdasarkan pencapaian program kerja memang terlihat bahwa pencapaian kinerja 
yang optimal dalam organisasi Universitas PGRI Palembang belum mencapai hasil yang diharapkan. Rendahnya kinerja ini ditunjukkan dari lemahnya mereka dalam penyelesaian-penyelesaian suatu pekerjaan sebagai contoh nyata, penyelesaian laporan semester yang merupakan tugas rutin seringkali mengalami keterlambatan dalam penyelesaiannya, proses pencetakan nilai mahasiswa yang lambat, penyusunan jadwal yang sering terlambat membuat pelayanan terhadap mahasiswapun menjadi terhambat. Hal ini disebabkan banyak faktor salah satunya kurangnya koordinasi serta pembagian tugas dalam pelaksanaannya selama ini, serta disiplin pegawai terhadap pekerjaan yang masih rendah. Kondisi tersebut membuat Pencapaian maksimal dalam pelaksanaan program kerja seringkali belum mencapai target, padahal Universitas PGRI sudah mempunyai tenaga administrasi cukup banyak. Akan tetapi pada kenyataannya kinerja yang ditunjukan sama sekali masih belum maksimal. Hal lain yang juga menunjukkan bahwa motivasi yang ada relatif rendah yang tergambar dari sikap disiplin karyawan dalam melakukan atau menyelesaikan suatu pekerjaan.

Selain itu tingkat loyalitas pegawai universitas PGRI Palembang serta kesadaran akan kedisipilinan dalam bekerja memang masih cukup rendah, banyak pegawai yang bolos bekerja, tidak hadir sampai berbulanbulan lamanya, sering terlambat datang merupakan pemandangan yang ironis bagi sebuah lembaga universitas yang sedang mengalami perkembangan yang cukup pesat. Motivasi serta tingkat loyalitas pegawai di Universitas PGRI Palembang memang terasa masih sangat kurang terhadap lembaga, di tambah lagi sikap profesional layaknya sebagai administrator publik memang belum tumbuh pada jiwa pegawai Universitas PGRI Palembang, sehingga pemaksimalan pencapaian target pada program kerja yang telah ditetapkan menjadi tidak maksimal.

Kondisi pencapaian hasil kinerja pegawai yang tidak maksimal menjadi suatu hal yang menarik untuk diteliti sehingga akan bermanfaat bagi lembaga Universitas PGRI Palembang ini.

\section{METODE PENELITIAN}

Populasi dalam penelitian ini adalah pegawai administrasi Universitas PGRI Palembang yang berjumlah 381 orang. Sedangkan karakteristik populasi adalah pegawai yang melaksanakan pekerjaan administrasi dan pegawai yang melaksanakan pekerjaan administrasi sekaligus sebagai dosen tenaga pengajar di Universitas PGRI Palembang. Tidak termasuk dosen sebagai tenaga pengajar akademik. 
Untuk mengambil sampel yang akan digunakan pada penelitian ini, penulis menggunakan teknik Proportionate Stratified Random Sampling dimana cara pengambilan anggota sampel dari populasi dilakukan secara proporsional dengan memperhatikan strata yang ada dalam populasi itu, (Sugiono, 2005: 93). Dengan jumlah populasi sebanyak 381 orang yang dikelompokkan berdasarkan tingkat pendidikan pegawai dengan didasarkan bahwa pengambilan sampel berdasarkan tingkat pendidikan ini adalah untuk melihat bagaimana tanggapan responden dari berbagai kalangan dengan tingkat pola pikir yang berbeda dengan didasarkan pada strata pendidikan tersebut atas permasalahan yang ada di lembaga Universitas PGRI Palembang. Maka jumlah sampel yang akan diambil berdasarkan pendapat Arikunto (2002) adalah dengan mengambil secara acak dari tiap strata sebanyak $10 \%$ x jumlah populasi pada setiap strata pendidikan maka didapatlah jumlah sampel 39 orang.

Metode pengumpulan data menggunakan dua sumber data yang meliputi Kuesioner yang disebarkan bersifat tertutup, dengan jaminan bahwa kerahasian atas jawaban tetap terjaga dan tidak ada pengaruh apapun terhadap sampel. Dokumentasi berupa dokumen-dokumen yang ada di Kantor Universitas PGRI Palembang dan literatur-literatur yang ada kaitannya dengan permasalahan yang menjadi bahan dalam penelitian ini. Agar kuesioner yang telah dikembalikan tidak bias, maka terlebih dahulu perlu dilakukan Uji Validitas (Test of Validity) dan Reliabilitas (Test of Reliability).

\section{Analisis Statistik Deskriptif}

Analisis statistik deskriptif digunakan untuk memperoleh gambaran mengenai variabel penelitian yang terdiri dan motivasi, kemampuan, kepemimpinan dan kinerja pegawai. Pada analisis ini dilakukan perhitungan terhadap distribusi frekuensi dari data penelitian, hubungan antara variabel dan analisis deskriptif lainnya.

\section{Analisis Jalur (Path Analysis)}

Langkah-langkah untuk menghitung besarnya koefesien jalur pada penelitian ini didasarkan pada nilai koefesien regresi sebagai berikut (Sitepu, 1994): hitung koefesien regresi; hitung koefesien jalur pengaruh variabel lain yang tidak dimasukkan ke dalam model; dan pengujian koefesien jalur dilakukan dalam dua tahap 1) pengujian secara keseluruhan (simultan) dengan menggunakan statistik uji-F; 2) Pengujian secara parsial dilakukan dengan statistik uji-t. 


\section{HASIL PENELITIAN DAN}

\section{PEMBAHASAN}

Hasil uji validitas dari 1-15 item pertanyaan untuk variabel Motivasi terlihat Artinya semua item yang ada pada variabel tersebut dapat dijadikan indikator yang valid dalam penelitian. Hasil uji validitas dari 25 item pertanyaan/pernyataan untuk variabel Kepemimpinan terlihat item pernyataan yang ada pada kuesioner tersebut semua item valid pada taraf nyata 5\%. Artinya, bahwa semua item pernyataan secara statistik valid dan dapat digunakan sebagai indikator pada variabel Kinerja Pegawai dan dapat digunakan sebagai alat penelitian.

Untuk uji reliabilitas hasilnya didapat Hasil perhitungan nilai reliabilitas Cronbach Alpha untuk variabel Motivasi dengan bantuan program SPSS adalah sebesar 0.938. Artinya dari 15 item pernyataan yang dijadikan sebagai indikator variabel Motivasi $\left(\mathrm{X}_{1}\right)$ sangat reliabel.

\section{Analisis Deskriptif}

Hasil analisis secara deskriptif pada masing-masing variabel untuk variabel Motivasi, Kepemimpinan dan Kinerja pegawai pada Universitas PGRI Palembang menunjukkan pada kategori baik. Hal ini ditandai dengan jawaban responden yang sebagian besar menyatakan pada kategori yang baik. Hasil pengujian hipotesis dan hasil analisis yang dilakukan di atas dapat dijelaskan sebagai berikut:

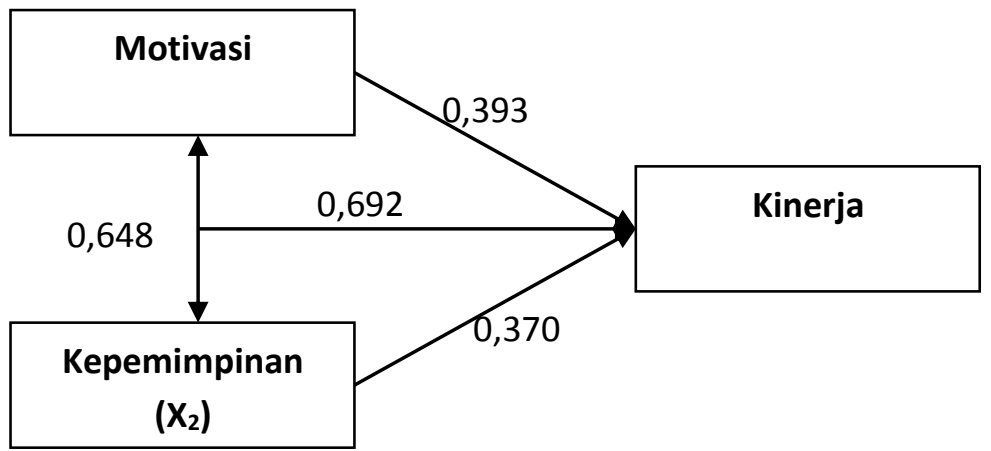

Berdasarkan gambar di atas dapat dijelaskan sebagai berikut:
1. Besarnya pengaruh variabel motivasi terhadap kinerja: 
a. Besarnya pengaruh langsung adalah: $0,393 \times 0,393=0,154$

b. Besarnya pengaruh tidak langsung adalah: $0,393 \times 0,648 \times$ $0,370=0,094$

Jadi besarnya pengaruh motivasi terhadap kinerja baik secara langsung maupun tidak langsung adalah sebesar 0,248 atau 24,8 persen.

2. Besarnya pengaruh variabel kepemimpinan terhadap kinerja:

a. Besarnya pengaruh langsung adalah: $0,370 \times 0,370=0,137$

b. Besarnya pengaruh tidak langsung adalah: $0,393 \times 0,648 \times$ $0,370=0,094$

Jadi besarnya pengaruh

kepemimpinan terhadap kinerja baik secara langsung maupun tidak langsung adalah sebesar 0,231 atau 23,1 persen.

3. Besarnya pengaruh motivasi dan kepemimpinan secara simultan terhadap kinerja adalah $24,8+23,1=$ 47, 9 persen atau sebesar $\mathrm{R}^{2}=$ $(0,692)^{2}=0,479$

Sebelum diambil suatu kesimpulan untuk membuktikan atau menjawab hipotesis yang ada apakah variabel-variabel tersebut berpengaruh terhadap variabel Kinerja (Y), maka koefesien regresi di atas perlu dilakukan pengujian baik secara simultan maupun secara parsial.

\section{Pengujian Secara Simultan}

Diperoleh nilai F-hitung sebesar 16,585 atau nilai p-value (Sig.) sebesar 0,000. Karena nilai p-value $<\alpha$, maka $\mathrm{H}_{0}$ ditolak. Artinya, pada taraf nyata sebesar 5\% dapat dinyatakan bahwa ada pengaruh yang nyata antara Motivasi dan Kepemimpinan secara bersama-sama terhadap Kinerja pegawai di Universitas PGRI Palembang.

Besarnya pengaruh kedua variabel tersebut dapat dilihat dari nilai koefesien determinasi sebesar 0,48. Artinya besarnya pengaruh variabel Motivasi dan Kepemimpinan secara bersama-sama terhadap kinerja pegawai di Universitas PGRI Palembang sebesar 48 persen.

\section{Pengujian Secara Parsial}

Karena dari hasil pengujian secara simultan menunjukkan ada pengaruh yang nyata antara Motivasi dan Kepemimpinan secara bersama-sama terhadap Kinerja pegawai, maka langkah selanjutnya akan dilakukan pengujian secara parsial untuk melihat faktor mana yang berpengaruh nyata terhadap Kinerja pegawai. Hasil pengujian koefesien regresi secara parsial dapat dilihat pada Tabel 5.18. Berdasarkan tabel tersebut dapat diambil kesimpulan sebagai berikut: 
1. Koefesien regresi untuk variabel Motivasi diperoleh sebesar 0,264 dan nilai t-hitung sebesar 2,491 dengan $p$ value sebesar 0,018. Karena p-value < 5\%, maka $\mathrm{H}_{0}$ ditolak. Artinya dengan kepercayaan sebesar $95 \%$ dapat dinyatakan bahwa variabel Motivasi berpengaruh nyata terhadap kinerja pegawai. Hal ini berarti jika variabel Kepemimpinan dianggap tetap, maka peningkatan Motivasi akan meningkatkan Kinerja Pegawai.

2. Koefesien regresi untuk variabel Kepemimpinan diperoleh sebesar 0,279 dengan nilai t-hitung sebesar 2,343 dan $p$-value sebesar 0,025. Karena $p$-value < 5\%, maka $\mathrm{H}_{0}$ ditolak. Artinya dengan kepercayaan sebesar $95 \%$ dapat dinyatakan bahwa variabel Kepemimpinan berpengaruh nyata terhadap kinerja pegawai. Hal ini berarti jika variabel Motivasi dianggap tetap, maka semakin baik Kepemimpinan akan meningkatkan kinerja pegawai.

Pengaruh Motivasi terhadap Kinerja Pegawai

Hasil pendugaan dengan metode kuadrat terkecil diperoleh nilai koefesien regresi untuk variabel Motivasi terhadap kinerja pegawai sebesar 0,264 dan hasil pengujian terhadap hipotesis menunjukkan signifikan pada taraf 5\%. Artinya, meskipun Kepemimpinan tetap, jika tingkat Motivasi meningkat maka kinerja pegawai juga menigkat lebih baik. Hal ini menunjukkan adanya pengaruh yang nyata antara Motivasi terhadap kinerja pegawai. Besarnya pengaruh Motivasi terhadap kinerja pegawai ditentukan oleh dimensi kebutuhan akan berprestasi, kebutuhan akan berafiliasi dan kebutuhan akan kekuasaan.

Berdasarkan hasil pengamatan penulis di lapangan dan hasil wawancara melalui kuesioner menunjukkan bahwa kondisi Motivasi yang terjadi pada Universitas PGRI Palembang telah menunjukkan hasil yang relatif baik, meskipun ada beberapa hal yang masih di rasa kurang optimal, sehingga perlu dilakukan instrospeksi diri bagi para pemimpin di Universitas PGRI Palembang, sehingga para pegawai merasa nyaman dan memiliki motivasi tinggi untuk berprestasi lebih baik lagi.

Hasil pengujian hipotesis dengan analisis statistik menunjukkan signifikan pada taraf 5\%. Hal ini berarti bahwa ada pengaruh positif yang nyata dari Motivasi terhadap kinerja pegawai di Universitas PGRI Palembang. Artinya, semakin baik Motivasi maka kinerja pegawai di Universitas PGRI Palembang juga semakin baik. 


\section{Pengaruh Kepemimpinan \\ terhadap}

\section{Kinerja Pegawai}

Hasil analisis diperoleh nilai koefesien regresi Kepemimpinan terhadap Kinerja pegawai sebesar 0,279 dan signifikan pada taraf 5\%. Artinya, meskipun pelaksanaan Motivasi dianggap tetap, maka Kepemimpinan yang semakin baik akan meningkatkan Kinerja pegawai. Berdasarkan hasil pengujian terhadap koefesien regresi menunjukkan signifikan pada tingkat kepercayaan sebesar 95\%. Hal ini menunjukkan adanya pengaruh yang nyata antara Kepemimpinan terhadap Kinerja pegawai.

Berdasarkan hasil pengamatan penulis di lapangan dan hasil kuesioner menunjukkan bahwa Kepemimpinan yang terjadi pada Universitas PGRI Palembang telah menunjukkan kondisi yang relatif baik, meskipun ada beberapa hal yang masih di rasa kurang kondusif. Kondisi Kepemimpinan yang terlihat baik dari dimensi pembinaan, dimensi hubungan timbal balik, dimensi teladan, dan dimensi komunikasi.

Hasil pengujian hipotesis dengan analisis statistik menunjukkan bahwa Kepemimpinan signifikan pada taraf 5\% terhadap kinerja pegawai. Hal ini berarti bahwa ada pengaruh positif yang nyata dari Kepemimpinan terhadap kinerja pegawai di

\section{Pengaruh Motivasi dan Kepemimpinan terhadap Kinerja Pegawai}

Dari hasil analisis korelasi berganda (multiple) diperoleh nilai korelasi antara Motivasi dan Kepemimpinan dengan Kinerja pegawai sebesar 0,48 . Hal ini menunjukkan bahwa ada hubungan positif yang sangat kuat antara Motivasi dan Kepemimpinan secara bersama-sama dengan Kinerja pegawai. Artinya, semakin tinggi Motivasi dan semakin kondusif Kepemimpinan secara bersama-sama maka kinerja pegawai semakin meningkat.

Nilai koefesien determinasi $\left(\mathrm{R}^{2}\right)$ Motivasi dan Kepemimpinan terhadap kinerja pegawai sebesar 0,48. Artinya, pelaksanaan Motivasi dan Kepemimpinan berpengaruh sebesar 48 persen terhadap kinerja pegawai. Hal ini menunjukkan adanya pengaruh positif yang nyata antara Motivasi dan Kepemimpinan terhadap kinerja pegawai di Universitas PGRI Palembang.

Berdasarkan hasil kuesioner menunjukkan bahwa kinerja pegawai akan meningkat jika Motivasi dan Kepemimpinan yang baik dapat tercipta dengan baik. Hal ini 
menunjukkan bahwa dari hasil pengamatan menunjukkan bahwa Motivasi dan Kepemimpinan baik secara individu maupun secara bersama-sama berpengaruh terhadap kinerja pegawai.

Kepribadian dari para pegawai sangat menentukan baik buruknya hasil kerja. Pegawai yang mempunyai kepribadian yang baik tentunya akan mempunyai kinerja yang optimal. Kepandaian akan menjadikan seorang pegawai cepat dan tepat dalam melakukan tugas dan pekerjaannya, baik kepandaian itu berasal dari pendidikan ataupun dari pengalaman. Inisiatif para pegawai dalam menyelesaikan tugas dan pekerjaannya juga sangat mempengaruhi hasil kerja, semakin tinggi daya inisiatif dalam menyelesaikan tugas dan pekerjaannya, maka hasil kerja juga bisa optimal.

Untuk menyelenggarakan tugas pemerintahan, diperlukan adanya perencanaan yang baik yang dilaksanakan dalam suatu organisasi sehingga menyebabkan adanya pergerakkan dalam organisasi, karena sifat organisasi itu dinamis bukan statis yang pada akhirnya memerlukan pengawasan dari atasan terhadap pelaksanaan tugas bawahannya agar tidak terjadi penyimpangan dari rencana yang sudah ditetapkan. Kinerja yang baik memerlukan suatu perencanaan yang baik pula yang disusun sedemikian rupa yang memerlukan koordinasi dengan pihak-pihak terkait dalam rangka mencapai tujuan, karena suatu pekerjaan tanpa perencanan yang baik maka hasil yang didapat tidak akan memuaskan. Peran camat selaku pimpinan dalam menggerakkan bawahannya sangat penting disamping itu kepemimpinan dari atasan juga mempengaruhi pelaksanaan tugas bawahannya.

Hasil penelitian ini sependapat dengan Winardi,(2001: 207) bahwa bekerja tanpa motivasi akan cepat bosan, karena tidak adanya unsur pendorong. Motivasi mempersoalkan bagaimana caranya gairah kerja pegawai, agar pegawai mau bekerja keras dengan menyumbangkan segenap kemampuan, pikiran, keterampilan untuk mewujudkan tujuan organisasi. Motivasi merupakan suatu kekuatan potensial yang ada pada diri seseorang manusia, yang dapat dikembangkannya sendiri, atau dikembangkan oleh sejumlah kekuatan luar yang pada intinya sekitar imbalan moneter, dan imbalan non moneter, yang dapat mempengaruhi hasil kinerjanya secara positif atau negative, hal mana tergantung pada situasi dan kondisi yang dihadapi orang yang bersangkutan. 


\section{Daftar Pustaka}

Arikunto, Suharsimi, 2005, Prosedur Penelitian, Jakarta, Rineka Cipta.

Nugroho Riant, 2000, Kebijakan Publik, Elex Media Komputindo, Jakarta

Peraturan Pemerintah No. 60 tahun 1999.

Sugiyono, 2005, Metode Penelitian Administrasi, Cetakan ketiga Bandung, Penerbit Alfabeta.

Sugiyono, 2005, Statistika Untuk Penelitian, Penerbit Alfabeta Bandung

Sarwono Jonathan, 2007, Analisis Jalur Untuk Riset Dengan SPSS, CV. Andi Offset Bandung

Undang - undang No. 2 Tahun 1989 tentang Sistem Pendidikan Nasional dalam menyelenggarakan pendidikan perguruan tinggi dapat berbentuk Universitas, Sekolah Tinggi, Insititut, Politeknik, Akademi, yang diselenggarakan oleh pemerintah dan masyarakat (swasta)

Universitas PGRI Palembang, 2007, Evaluasi Akademik Penyelenggaraan Program Studi. Univ. PGRI Palembang.

Universitas PGRI Palembang (2007). Laporan Penyelenggaraan Universitas PGRI Palembang. Univ. PGRI Palembang.

Winardi, 2000. Motivasi dan Pemotivasian dalam Manajemen, PT. Raja Grafindo Persada, Jakarta 